\title{
Acquisition control and health monitoring of creep in concrete specimens
}

\section{Controle de aquisição e monitoração da fluência em corpos de prova de concreto}

L. T. KATAOKA a

luciana.kataoka@poli.usp.br

A. C. MARQUES

ana.marques@poli.usp.br

M. A. S. MACHADO

marceloasmachado@gmail.com

T. N. BITTENCOURT d

tulio.bittencourt@poli.usp.br

\begin{abstract}
Creep has been pointed out as one of the main causes of non-structural cracking in concrete structures. Nevertheless, their behavior on concretes made with current materials is scarcely known. The use of real time health monitoring systems of strains in structures has been demonstrated to be a high potential inspection and maintenance techniques. The aim of this paper is to contribute for the publication of acquisition control techniques and strain results from a one month health monitoring period for Brazilian commercial concrete cylindrical specimens. For that, the equipment DataTaker and the DeTransfer software was used.
\end{abstract}

Keywords: health monitoring, creep, data acquisition and concrete specimens.

\section{Resumo}

A fluência vem sendo apontada como uma das principais causas de patologias em estruturas de concreto. Todavia, o seu comportamento para concretos feitos com os cimentos nacionais atuais é conhecido de forma muito limitada. O uso de sistemas de monitoração de deformação em tempo real de estruturas tem demonstrado um grande potencial como técnicas de inspeção e manutenção. $O$ objetivo deste trabalho é contribuir para a divulgação de técnicas do controle de aquisição e resultados referentes ao período de um mês de monitoração da deformação por fluência em corpos de prova cilíndricos considerando um concreto de linha de produção brasileiro. Para tanto, utilizaram-se o equipamento DataTaker e o programa DeTransfer.

Palavras-chave: monitoração, fluência, aquisição de dados, corpos de prova de concreto.

\footnotetext{
${ }^{a}$ Department of Structural and Geotechnical Engineering, University of Sao Paulo, luciana.kataoka@poli.usp.br, Sao Paulo, Brazil

${ }^{b}$ Department of Structural and Geotechnical Engineering, University of Sao Paulo, ana.marques@poli.usp.br, Sao Paulo, Brazil

c Department of Structural and Geotechnical Engineering, University of Sao Paulo, marceloasmachado@gmail.com, Sao Paulo, Brazil

${ }^{d}$ Department of Structural and Geotechnical Engineering, University of Sao Paulo, tulio.bittencourt@poli.usp.br, Sao Paulo, Brazil
} 


\section{Introduction}

Concrete shows elastic as well as inelastic strains on loading, or creep, and reduction in volume, or shrinkage strains, due to moisture loss to the environment. The phenomenon of a gradual increase in strain with time under a given level of sustained stress is called creep (Mehta, Monteiro [1]).

Creep in concrete structures is one of the main causes of masonry damage due to excessive strains of the structural elements. Creep depends not only on the applied load but also on the environmental conditions. If these excessive strains are not detected and the caused damage not correctly repaired along the time, they may cause degradation and, eventually, structural collapse. As a result, they may lead to considerable economical and social costs.

In this sense, the characterization of creep in the concrete specimen by health monitoring has been broadly studied. Indeed, creep represents one of the most uncertain mechanical properties of concrete because the statistical scatter of measurements and its constituent materials differ from country to country (Videla [2] and Bazant, Li [3]). Standard creep test methods can predict strains along the time and, consequently, structural failures, enhancing the service life of the structures. With the advance of the portable computer technology, automated control acquisition systems make feasible the health monitoring of structures in real time.

This paper is part of an ongoing research project designated to the study of the deformability of the concrete along the time. The aim of this research project is the characterization of creep and shrinkage of the Brazilian concretes. In this sense, this paper intends to describe an acquisition control technique utilized to measure creep strains in laboratory and to publish results from a one-month health monitoring period of cylindrical specimens made with conventional concrete.

\section{Materials for creep test method}

The test method to measure creep in laboratory was conducted utilizing 15 by $30 \mathrm{~cm}$ cylindrical specimens cast with conventional concrete. This concrete had $30 \mathrm{MPa}$ of compressive strength at 28 days, and the mix proportion was $1: 2.8: 3.7 ; 0.56$, which represented the constituent materials of the concrete (cement : fine aggregate : coarse aggregate ; water). In the present study, Portland cement CPIII-40RS was used. This type of cement corresponds to a cement type with a low strength development and a slag proportion up to $60 \%$ in substitution of the clinker. The coarse aggregate consisted of $19 \mathrm{~mm}$ maximum size limestone with a specific mass of $2.70 \mathrm{~g} / \mathrm{cm}^{3}$. The fine aggregate was a mixture of two different types of sands: natural sand and limestone sand with maximum size of 1.2 and $2.4 \mathrm{~mm}$, respectively. The limestone sand was the residue from the coarse aggregate production. The specific mass was $2.68 \mathrm{~g} / \mathrm{cm}^{3}$ and $2.64 \mathrm{~g} / \mathrm{cm}^{3}$ for limestone and natural sand, respectively. The fineness modulus was 2.70 and 1.25 for limestone and natural sand, respectively. A water-reducing type admixture with a density of $1.2 \mathrm{~g} / \mathrm{cm}^{3}$ was employed to achieve the desired workability of $100 \mathrm{~mm}$ in the concrete mixture.

The test was conducted in a controlled temperature and relative humidity room, $23 \pm 1^{\circ} \mathrm{C}$ and $60 \pm 4 \%$, respectively.
Figure 1 - Embedded electrical strain gage

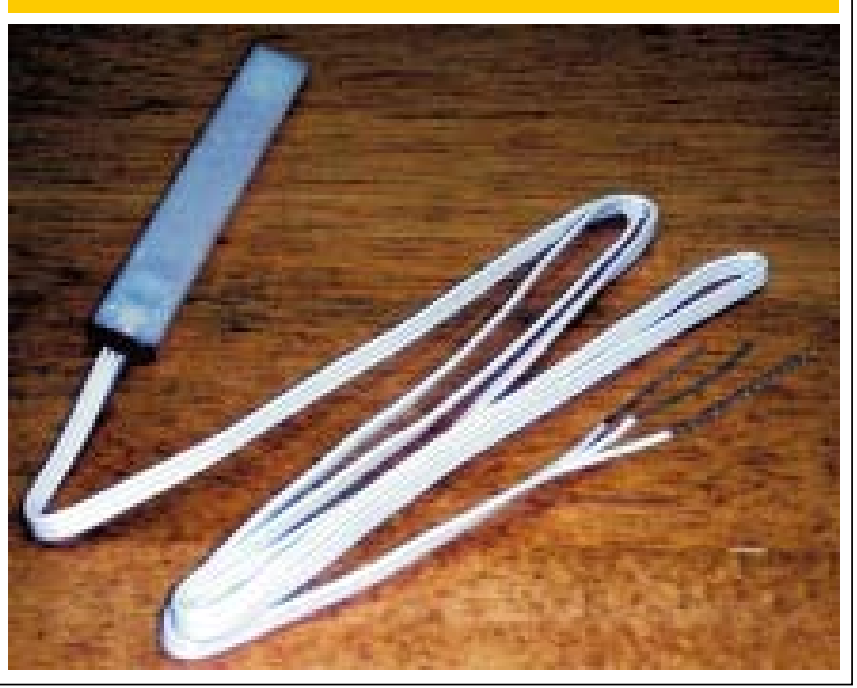

Embedded resistive electrical strain gages, capacitive humidity sensor based on polymer, and temperature PT100 sensors was used. The embedded resistive electrical strain gage has $120 \Omega \pm 1 \%$, 3 -wire quarter-bridge circuit, and gage factor of 2 . It is involved in a vinyl-coated flat to protect it from humidity during the cast, and sized $120 \times 15 \times 5 \mathrm{~mm}$. This strain gage requires other 3 resistive elements (resistors of $120 \Omega \pm 1 \%$ ) to complete the Wheatstone bridge for monitoring the measurements. Furthermore, this strain gage presents self-temperature-compensation range from 0 to $50^{\circ} \mathrm{C}$. However, its operating temperature range is from -10 to $70^{\circ} \mathrm{C}$ (Figure [1]).

The temperature sensor is a thermo-resistance PT100 type. This sensor is a 3-wire cable type and is made of stainless steel case, isolated with PVC. Moreover, it operates up to $90^{\circ} \mathrm{C}$ of temperature, and had precision of $1 \%$ (Figure [2]).

The humidity sensor has also precision of $1 \%$, and operates in a range from 45 to $98 \%$.

Taking into account that the embedded electrical strain gage has tolerance of $1 \%$, the bridge completion has to be made with resistors of at least $1 \%$ of precision. Therefore, the resistor used in this work is a $0.4 \mathrm{~W} 1 \% 120 \Omega$ type. Its temperature coefficient was $50 \mathrm{ppm} /{ }^{\circ} \mathrm{C}$. This resistor operates in a temperature range from -55 to $155^{\circ} \mathrm{C}$.

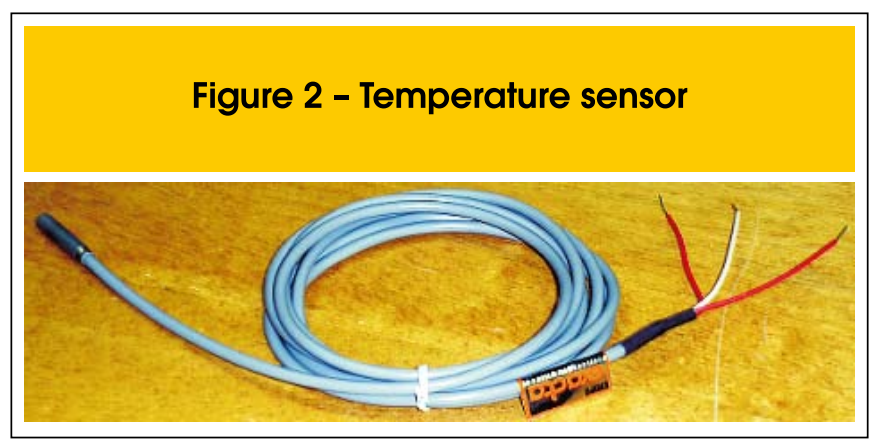




\section{Figure 3 - Expansion module and DataTaker DT600}

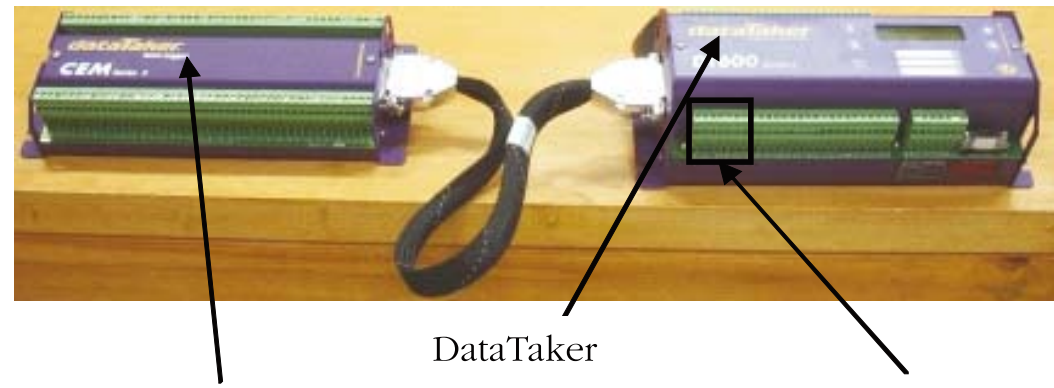

Expansion module

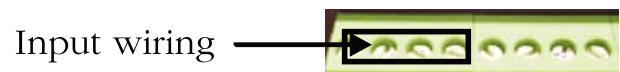

Wiring label $(*+-\mathrm{R})$

\section{DataTaker and DeTransfer}

In this research, the equipment DataTaker and the DeTransfer software were used.

DataTaker is a leading supplier of data loggers and data recording equipments to a broad range of customers throughout industry, public utilities, scientific and educational institutions, according to the Technical Manual [4]. Specifically, the DataTaker DT600 model enables the use of different types of sensors in ten analogical channels (Figure [3]). This model provides a channel expansion module with 10 channels controlled by the principal module (Figure [3]).
DT600 stores data in internal memory up to $1,390,000$ data points (DataTaker + expansion module). This internal memory allows the connection between the computer and the equipment only to send commands and to download data by an RS232 cable. DT600 can be powered from source AC (11 to $24 \mathrm{Vdc}$ ), source DC (9 to 18 $\mathrm{Vac}$ ) and battery (6 to $9 \mathrm{Vdc}$ ).

The software DeTransfer provides many tools for communicating with DT600. The workspace contains one or more send and receive sub-windows (Figure [4]). In the send sub-window, it is possible to create, edit, and save programs. The receive sub-window presents real-time information (information as it is returned from

\section{Figure 4 - Workspace of DeTransfer (Technical Manual (4))}

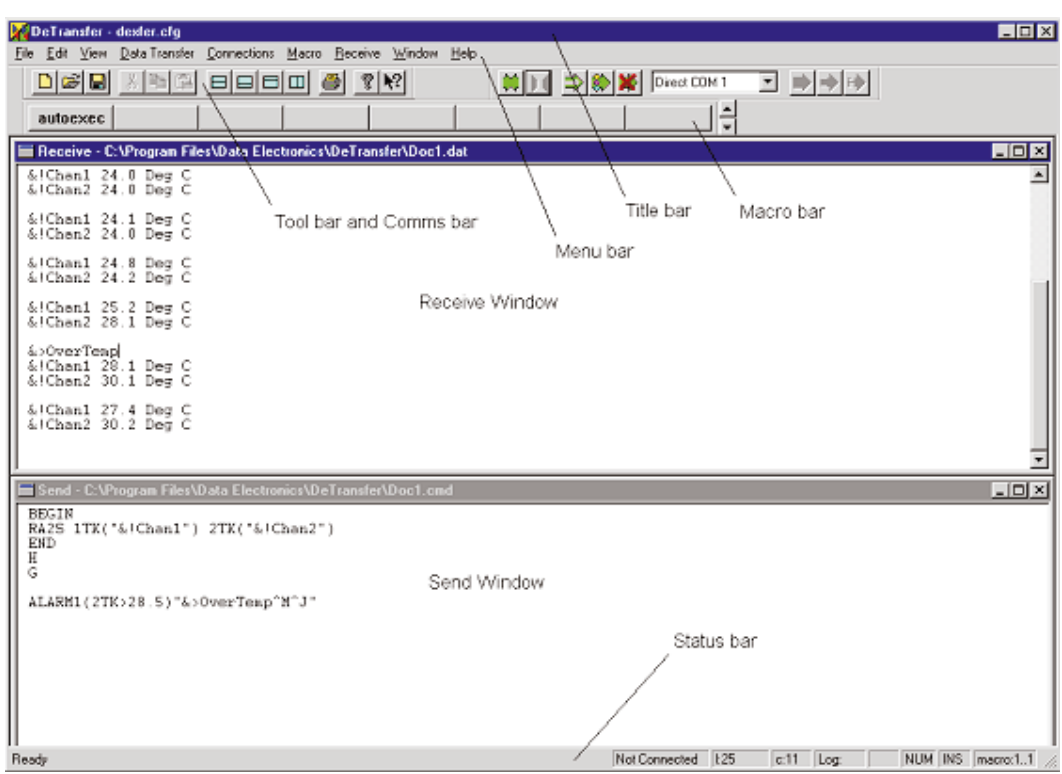


Table 1 - DeTransfer commands

\begin{tabular}{|c|c|c|c|c|c|c|}
\hline Sensor type & $\begin{array}{l}\text { Signal } \\
\text { Category }\end{array}$ & $\begin{array}{l}\text { Channel } \\
\text { type label }\end{array}$ & $\begin{array}{c}\text { Default channel } \\
\text { options }\end{array}$ & Resol. & $\begin{array}{l}\text { Output } \\
\text { units }\end{array}$ & Examples \\
\hline $\mathrm{R}, \mathrm{H}^{*}{ }^{*}$ & Current & $\mathrm{L}$ & $(100)^{\star \star}$ & 0.01 & percent & $2 \mathrm{~L}(100)$ \\
\hline Temp. & Temp. & PT385 & & 0.1 & ${ }^{\circ} \mathrm{C}$ & 5РТ385 \\
\hline Strain gage & Bridge & $\mathrm{BGI}$ & $(350)^{\star * *}$ & 0.1 & ppm & $1 \mathrm{BGI}(120,4 \mathrm{~W})$ \\
\hline
\end{tabular}

DT600 - measured data, echoes of its commands, test and status information), and data from the DT600's internal memory and configuration. DeTransfer has specific commands to control the acquisition rate, the data storage in the internal memory, the internal parameter configurations of DT600, and the alarm settings.

Among several sensors that DT600 accepts, this paper only presents the wiring configuration of circuits designed for the sensors described in 2. The commands used for these sensors are presented in Table [1].

A typical command line for any sensor can be presented as:

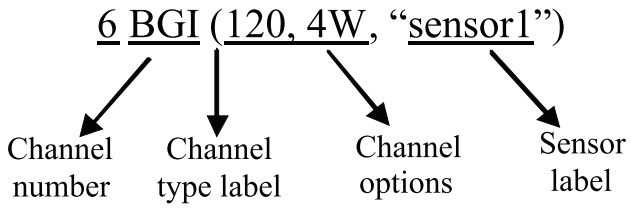

\subsection{Relative humidity}

The humidity sensor requires an extra external shunt resistor (resistor

Figure 5 - Wiring configuration for the humidity sensor (Technical Manual (4))

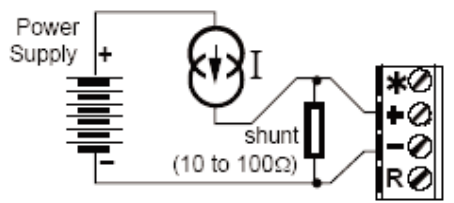

Figure 6 - Wiring configuration for the temperature sensor (Technical Manual (4))

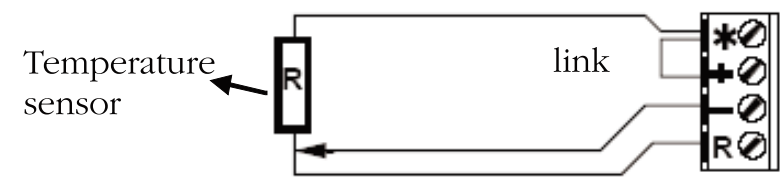

of $100 \Omega$ ) for monitoring the measurements. Besides, it is necessary a power supply connected in the channel negative input (Figure [5]).

\subsection{Temperature}

The wiring configuration representing the connection between the temperature sensor and the DataTaker is shown in Figure [6].

\subsection{Strain}

DT600 provides two internal potentiometers which complete the Wheatstone bridge with other two external resistive elements. Therefore, it is necessary only a single external resistor, besides the strain gage, for monitoring the measurements. Moreover, DT600 allows multiple 3-wire quarter-bridge inputs using only one resistor for all channels. In this case, the bridge completion resistor is shared among the utilized channels. Its input resistance is equal to the nominal resistance value of the "unknown" resistor.

The wiring configuration of the multiple 3-wire quarter-bridge inputs is shown in Figure [7].

In order to convert DT600's ppm readings to strain $\left(\times 10^{-6}\right)$ for simulated bridge (i.e. only two resistive elements external to the logger), Equation [1] has to be used.

$k=\frac{2}{G^{*} N}$

Figure 7 - Wiring configuration for the resistive electrical strain gage (Technical Manual (4))

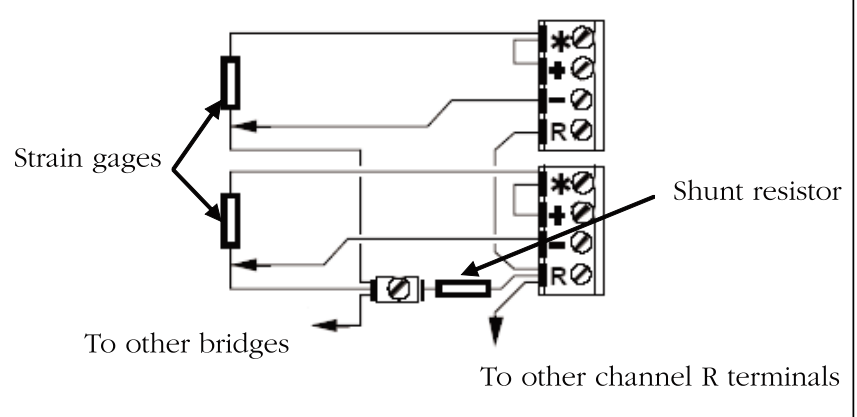




\section{Figure 8 - Controlled temperature and relative humidity room}

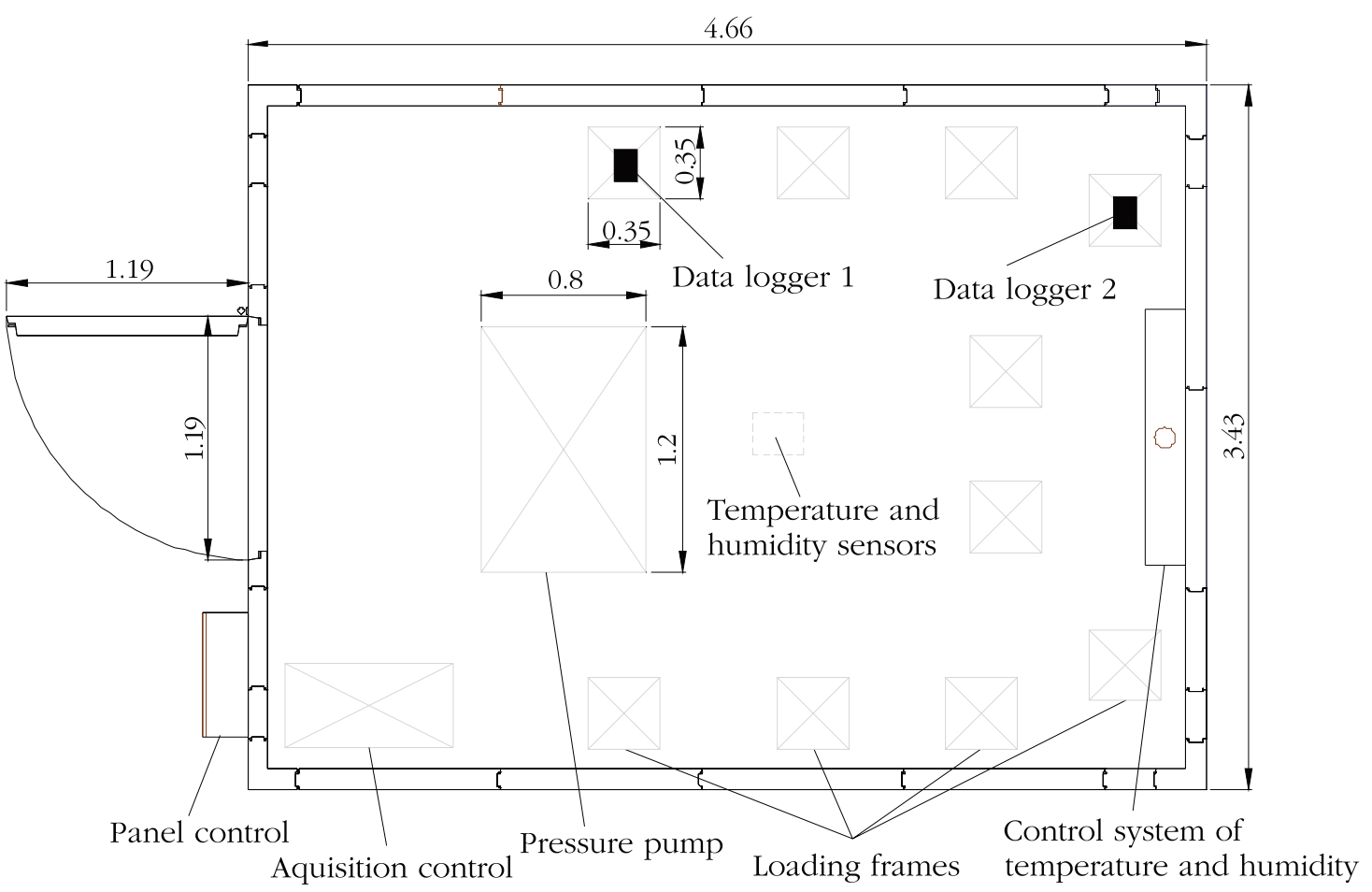

Where:

$G$ - gage factor

$\mathrm{N}$ - number of active gages in the bridge

\section{Test methodology}

This item presents the methodology used for preliminary tests, de-

\section{Figure 9 - Temperature and relative humidity of the controlled room}

Temperature ( $\left.{ }^{\circ} \mathrm{C}\right)$ and Relative humidity (\%) x Time

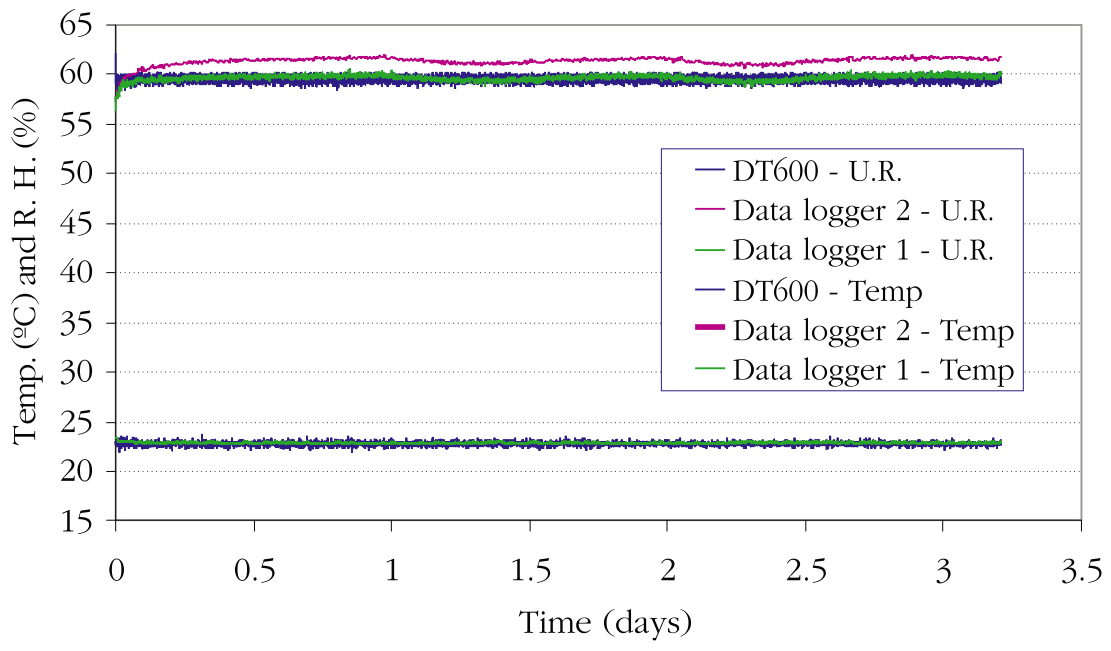


scribed in 4.1, and for the adopted acquisition control system and creep health monitoring, described in 4.2 .

\subsection{Preliminary tests}

In order to ensure the efficiency of the creep test, two preliminary tests were conducted: calibration of the controlled temperature and relative humidity room, where the creep tests were performed, and calibration of the utilized Wheatstone bridges.

\subsubsection{Calibration of the controlled temperature and relative humidity room}

The aim of this test was to verify that the controlled room was able to keep the temperature and the relative humidity constant in $23 \pm 1^{\circ} \mathrm{C}$ and in $60 \pm 4 \%$, respectively. For that, it was installed a signal retransmission board with temperature and humidity sensors placed on the internal ceiling of the controlled room. From the signal retransmission board, it was possible to monitor the measurements utilizing DT600 (Figure [8]).

Two extra data loggers were also used to check the temperature and humidity measurements from the controlled room. These data loggers were placed in two different positions inside the room in order to verify possible differential temperature and relative humidity (Figure [8]). The data loggers have uncertainty measurements of temperature and humidity of $\pm 0.3^{\circ} \mathrm{C}$ and $\pm 2 \%$, respectively.

It can be seen in Figure [9] that both temperature and relative humidity measured by the different sensors were within the acceptable tolerance of $23 \pm 1^{\circ} \mathrm{C}$ and $60 \pm 4 \%$ for the creep test.

\subsubsection{Calibration of the Wheatstone bridge}

The utilized Wheatstone bridges was calibrated using an electrical strain gage bonded in a steel bar cantilever (reinforcing bar) subjected to a point load of $618 \mathrm{~g}$ at the free end (Figure [10]). The bar cross-section was round and had $6.3 \mathrm{~mm}$ of diameter. The steel modulus of elasticity was $210 \mathrm{GPa}$. The strain gage had $120 \Omega \pm 1 \%$, 2-wire quarter-bridge circuit, and gage factor of 2.1. Thus, knowing the applied load and the material properties, it was possible to predict strains at the bar.

The analytical strains were calculated according to Equations (2) (3) and (4) from resistance of materials:

$\varepsilon=\frac{M * r}{E * I}$

$$
I=\frac{\pi * d^{4}}{64}
$$

$$
M=P * L
$$

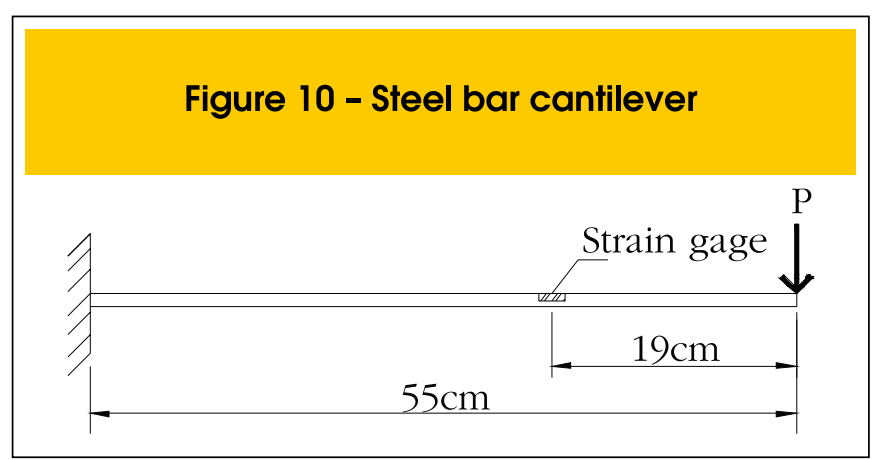

Where:

$\varepsilon$ - bar strain

$\mathrm{M}$ - bending moment

$r$ - bar radius

E - steel modulus of elasticity

I - moment of inertia

d - bar diameter

$\mathrm{L}$ - distance between point load and strain gage position

According to the analytical formulation, the predicted strain was $228 \times 10^{-6}$. If the difference between the measured and the analytical strains was up to an adopted value of $10 \times 10^{-6}(\approx 5 \%$ of the predicted strain), the Wheatstone bridge was considered to be calibrated. This method seemed to be efficient because of the linear elastic behavior of the steel for low levels of loading.

As shown in Figure [11], the average of the monitored strains was about $220 \times 10^{-6}$, which was within the adopted tolerance. This result indicated the efficiency of the calibration of the Wheatstone bridge.

\subsection{Creep test}

The creep test was conducted according to the Brazilian creep standard code [5]. Specifically, the adopted creep test method required some steps, such as:

- Instrumentation

This step consisted of placing the strain gage, so that the strain movement occurred along the longitudinal axis of the cylinder.

- Fabricating specimens

A sufficient number of cylindrical specimens (at least 6 ) were cast from the given batch of concrete for each test condition: three for compressive strength ( 10 by $20 \mathrm{~cm}$ cylindrical specimens), two to be loaded and observed for total strain ( 15 by $30 \mathrm{~cm}$ cylindrical specimens - SP1 and SP2) and one to remain unloaded (15 by $30 \mathrm{~cm}$ cylindrical specimen - SP3) and to be used as control to indicate strains due to causes other than load. The SP3 specimen was cast with both the electrical strain gage and the temperature PT100 sensor. In order to have plane faces perpendicular to the axis of the cylinder, steel plates were placed at the ends of the specimens during the cast. These plates ensured the planeness and uniformity of the load.

- Loading

All the specimens were kept in a controlled room at $23 \pm 2^{\circ} \mathrm{C}$ and up to $95 \%$ until the test date. Immediately before loading the creep specimens, the compressive strength of the strength specimens was determined. The specimens were placed in a loading frame and loaded using a hydraulic load-maintaining element and a pressure pump. The age at loading was 7 days and the specimens 


\section{Figure 11 - Experimental results from steel bar}

\section{Steel bar strain}

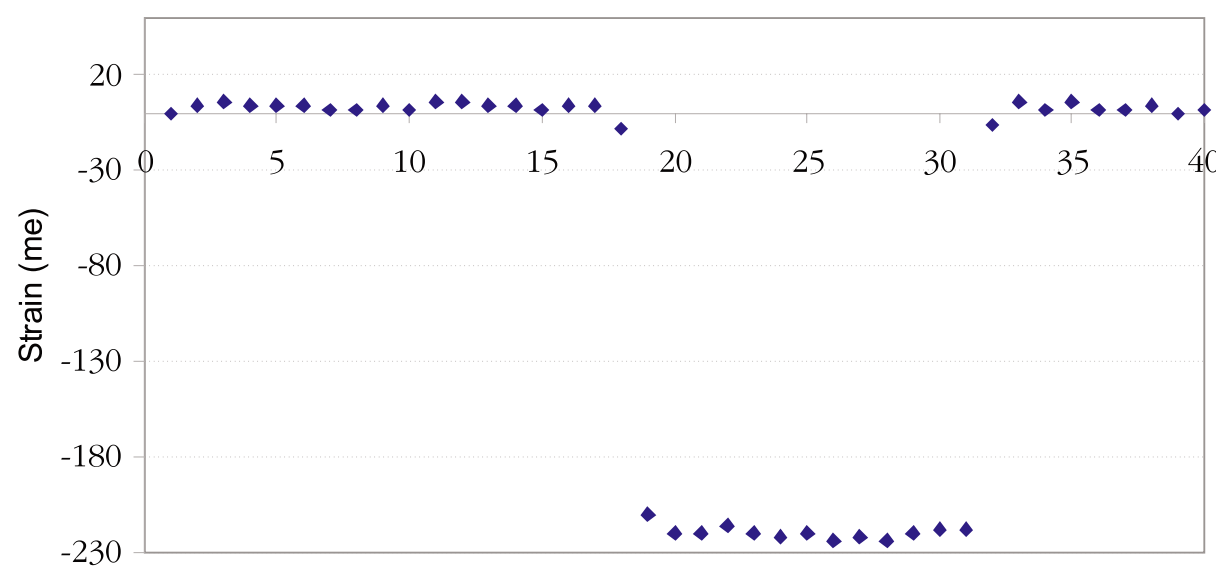

Time (seconds)

Table 2 - Detransfer commands for creep test

\begin{tabular}{|c|c|c|}
\hline Commentary & Command line & Option selected \\
\hline \multicolumn{3}{|c|}{ RESET } \\
\hline \multicolumn{3}{|c|}{ STATUS } \\
\hline \multicolumn{3}{|l|}{ Wait 3 seconds before the first reading } \\
\hline Force low power & $\mathrm{P} 15=1$ & Low \\
\hline Date format & $\mathrm{P} 31=1$ & European (dd/mm/yy) \\
\hline $\begin{array}{l}\text { Synchronizes all schedule's timing to } \\
\text { midnight }\end{array}$ & IS & Enable (CAPS) \\
\hline \multicolumn{3}{|c|}{$\mathrm{T}$} \\
\hline \multirow{3}{*}{$\begin{array}{l}\text { Synchronizes all schedule's timing and } \\
\text { date to the computer's }\end{array}$} & $T=\backslash T$ & \\
\hline & D & \\
\hline & $D=\backslash D$ & \\
\hline \multirow[t]{2}{*}{ Command block start } & BEGIN & \\
\hline & RA30S 1PT385("SP3-PT100") & $\begin{array}{l}\text { Reporting schedule RA } \\
\text { at } 30 \text { seconds }\end{array}$ \\
\hline \multicolumn{3}{|c|}{ 2BGI(120, "SP1") } \\
\hline \multicolumn{3}{|c|}{ 3BGI(120, "SP2") } \\
\hline \multicolumn{3}{|c|}{$4 B G \mid(120, " S P 3 ")$} \\
\hline \multicolumn{3}{|c|}{ IF1 (D>04/09/2008)"(RA1H)" (*) } \\
\hline \multicolumn{3}{|l|}{ Command block end } \\
\hline Command for going the schedules & $G$ & \\
\hline Global data logging & LOGON & Activated \\
\hline
\end{tabular}


Table 2 - DeTransfer commands for creep test

\begin{tabular}{|c|c|c|}
\hline Commentary & Command line & Option selected \\
\hline \multicolumn{3}{|c|}{ RESET } \\
\hline \multicolumn{3}{|c|}{ STATUS } \\
\hline \multicolumn{3}{|l|}{ Wait 3 seconds before the first reading } \\
\hline Force low power & $P 15=1$ & Low \\
\hline Date format & $P 31=1$ & European (dd/mm/yy) \\
\hline $\begin{array}{l}\text { Synchronizes all schedule's timing to } \\
\text { midnight }\end{array}$ & /S & Enable (CAPS) \\
\hline \multicolumn{3}{|c|}{$\mathrm{T}$} \\
\hline \multicolumn{3}{|l|}{ Synchronizes all schedule's timing and } \\
\hline \multicolumn{3}{|l|}{ date to the computer's } \\
\hline \multicolumn{3}{|c|}{$D=\backslash D$} \\
\hline \multirow[t]{2}{*}{ Command block start } & \multicolumn{2}{|l|}{ BEGIN } \\
\hline & RA30S 1PT385("SP3-PT100") & $\begin{array}{l}\text { Reporting schedule RA } \\
\text { at } 30 \text { seconds }\end{array}$ \\
\hline \multicolumn{3}{|c|}{$2 \mathrm{BGI}(120, " \mathrm{SP1}$ ") } \\
\hline \multicolumn{3}{|c|}{$3 B G \mid(120, " S P 2 ")$} \\
\hline \multicolumn{3}{|c|}{$4 B G \mid(120, " S P 3 ")$} \\
\hline \multicolumn{3}{|c|}{ IF1 (D>04/09/2008)" (RAIH)" (*) } \\
\hline \multicolumn{3}{|l|}{ Command block end } \\
\hline Command for going the schedules & Command for going the schedules & \\
\hline Global data logging & LOGON & Activated \\
\hline
\end{tabular}

were loaded at the intensity of $40 \%$ of the compressive strength at the age of loading (11.7MPa), according to the Brazilian creep standard code [5]. This level of stress is frequently utilized, since the prediction models of creep are restricted to stress levels up to this value. Moreover, Mehta, Monteiro [1] affirm that there is a direct proportionality between creep and the applied stress, when the level of stress is in the linear portion of the stress-strain relationship (i.e., up to $40 \%$ of the compressive strength).

\section{- Monitoring}

The strains readings were logged immediately before the application of the load and 30 seconds after that. The acquisition rate was 30 seconds during a period of 24 hours. Then, the rate was changed to 1 hour until the end of the test (37 days). Since the objectives of this health monitoring is to publish a data acquisition technique and to obtain results of creep strains, and most part of these strains occurs between 2 and 4 weeks, creep strains were monitored during only one month.

As shown in 3, DT600 is totally controlled via software by com- mands. Table [2] shows the specific command lines used to control the acquisition of the strains and temperatures from the conducted creep test, besides the internal parameter settings of DT600.

The health monitoring of total strain in concrete specimens is represented in Figure [12]. The creep strains were obtained by subtracting the strains of the control specimen from the total strains.

The logged data was downloaded via software and had the format *.DXU, which is compatible to the Microsoft Windows * .TXT extension.

\section{Creep results}

The 30-day data logged of strains and temperatures monitoring are shown in Figures [13] and [14], respectively.

From Figure [13], the strains of the control specimen was subtracted from the experimental total strains, resulting in creep strains, which can be seen in Figure [15]. Figure [15] also shows the predicted creep strains from creep prediction models available in 


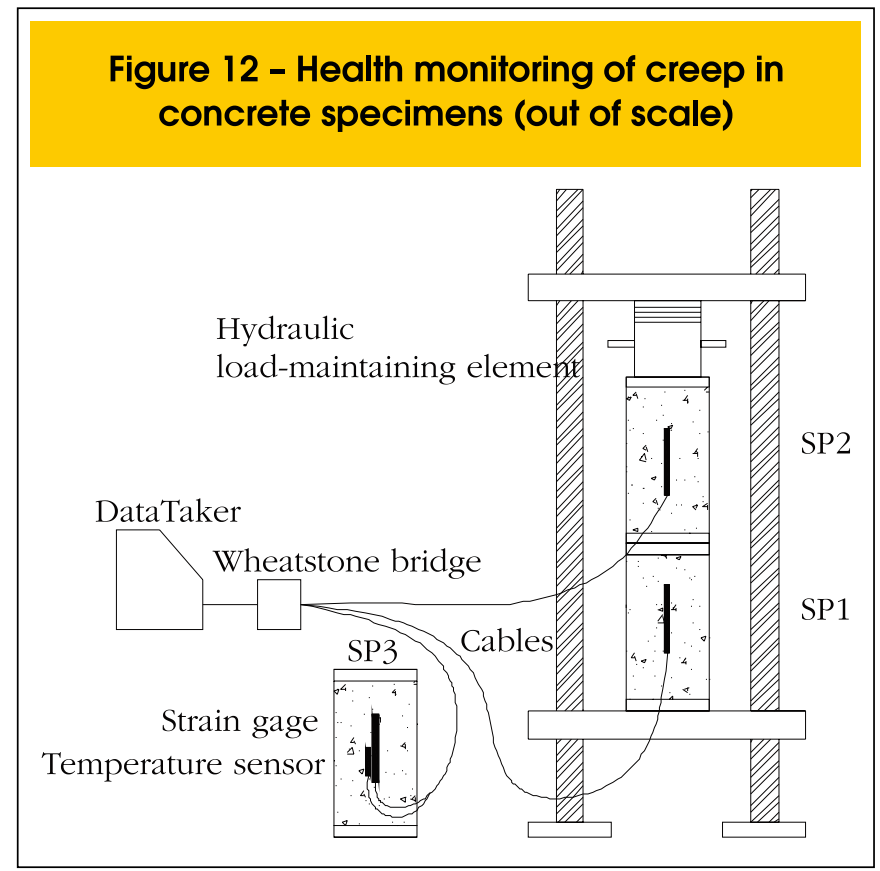

literature, such as: the European model - EC2 [6], the Brazilian model - NBR [7], and the Bazant and Baweja model - B3 [8]. The predicted creep strains served as a basis of reference in order to evaluate the magnitude of the experimental results. Table [3] presents the input parameters of the analyzed models.

The experimental creep strains were close to the predicted creep strains for the period of measurement. This analysis showed the efficiency of both acquisition control system and creep health monitoring.

\section{Conclusions}

From the present study, the following could be concluded:

- The preliminary tests were instrumental to the test creep achievement. First, the creep test was very sensitive to storage and environmental conditions (temperature and relative humidity). Then, the Wheatstone bridge calibration was essential for the correct monitoring strain;

- The experimental creep strains were close to the predicted creep strains for the period of 30 days;

- Both DT600 and DeTransfer were appropriate for the acquisition control and the health monitoring of specimens creep.

\section{Acknowledgements}

The authors acknowledge Fundo de Amparo a Pesquisa do Estado de Sao Paulo (FAPESP) and the ENGEMIX Concrete Company for providing financial and technical support for this research.

\section{References}

[01] Mehta, P. K.; Monteiro. P. J. M. Concrete Microstructure, Properties, and Materials, United States: McGrawHill, 3ed, 2006, pp.85-86.

[02] Videla, C.C. Modeling drying shrinkage of hardened Chilean concretes. Proc. of the SIABE06/INCOS06 (48 IBRACON) Simpósio Ibero-Americano sobre "Concreto Estrutural", Brasil: Rio de Janeiro, 2006.

[03] Bazant, Z.P., Li, G.H. Comprehensive Database on concrete Creep and Shrinkage. ACI Materials Journal, 105-M72, 2001, pp. 635-637.

\section{Figure 13 - Experimental total strains of the loaded and control specimens}

\section{Total strain}

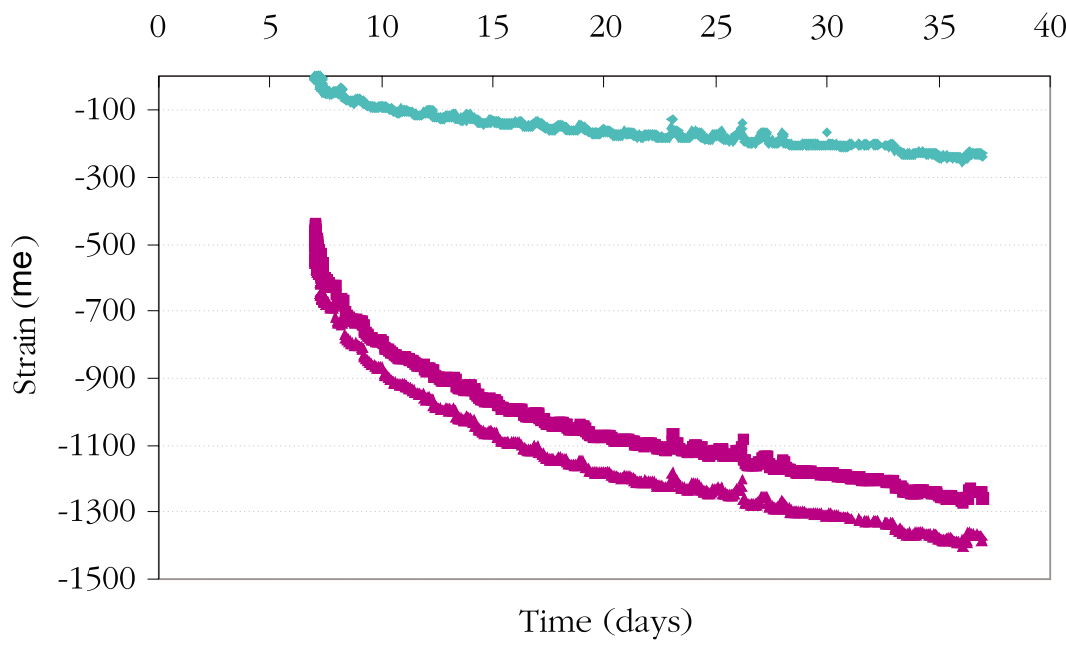




\section{Table 3 - Input parameters of creep models}

\begin{tabular}{|c|c|c|c|}
\hline \multirow{2}{*}{ Parameters } & \multicolumn{3}{|c|}{ Model } \\
\hline & EC2 & B3 & NBR \\
\hline Type of cement & $S$ & ASTMI & CPIII \\
\hline Relative humidity (\%) & 60 & 60 & 60 \\
\hline Age at loading (days) & 7 & 7 & 7 \\
\hline Type of cure & & moisture & \\
\hline volume/surface (mm) & & 38 & \\
\hline area/perimeter (mm) & 75 & & 87 \\
\hline Size $(\mathrm{mm})$ & $150 \times 300$ & $150 \times 300$ & $150 \times 300$ \\
\hline Age at cure (days) & & 7 & \\
\hline $\mathrm{f}_{\mathrm{cm+0}}(\mathrm{MPa})$ & 28 & & 28 \\
\hline $\mathrm{f}_{\mathrm{cm} 28}(\mathrm{MPa})$ & 40 & 40 & 40 \\
\hline $\mathrm{E}_{\mathrm{cmt0}}(\mathrm{GPa})$ & 27 & 25 & 25 \\
\hline $\mathrm{E}_{\mathrm{cm} 28}(\mathrm{GPa})$ & 30 & 30 & 30 \\
\hline Aggregate strength & limestone & & \\
\hline Aggregate content $\left(\mathrm{kg} / \mathrm{m}^{3}\right)$ & & 1915 & \\
\hline Cement content $\left(\mathrm{kg} / \mathrm{m}^{3}\right)$ & & 292 & \\
\hline Water content $\left(\mathrm{kg} / \mathrm{m}^{3}\right)$ & & 164 & \\
\hline Slump (mm) & & & 100 \\
\hline Temperature $\left({ }^{\circ} \mathrm{C}\right)$ & 23 & & 23 \\
\hline
\end{tabular}

Figure 14 - Experimental temperatures of the control specimen

Temperature of the specimen

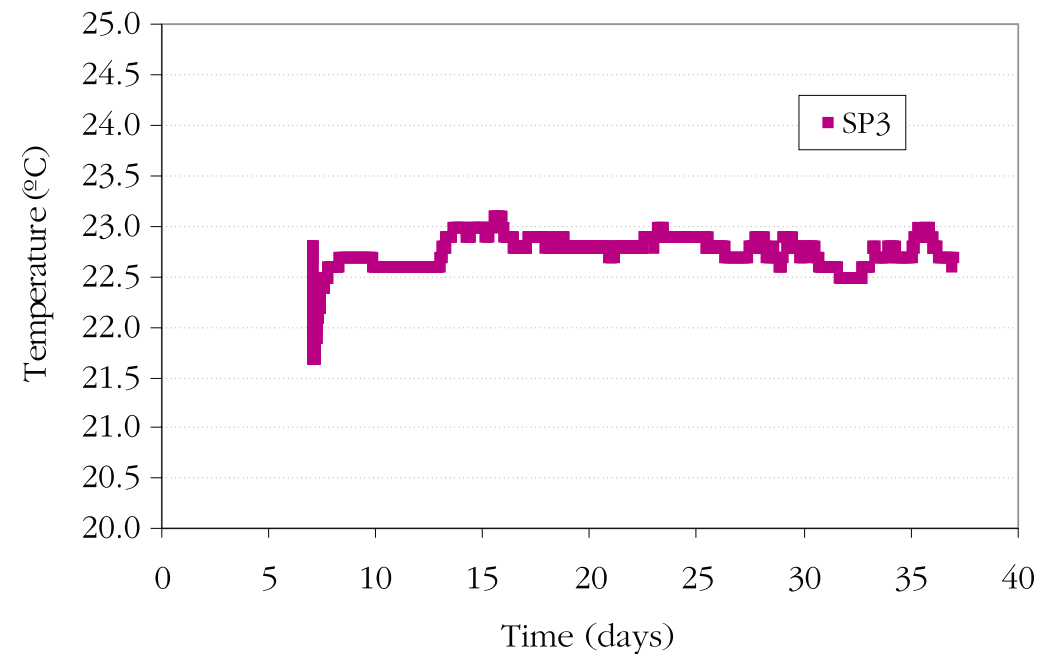


[04] DT600 User's Manual. www.datataker.com/products/dt600.html.

[05] ABNT - ASSOCIACAO BRASILEIRA DE NORMAS TECNICAS. Determinacao da fluencia - Método de Ensaio: NBR 8224, Rio de Janeiro, 1983.

[06] EC2 - Eurocode 2. Design of concrete structures Part 1.1: General rules and rules for buildings, 2003.
[07] ABNT - ASSOCIACAO BRASILEIRA DE NORMAS TECNICAS. Projeto de estruturas de concreto Procedimento: NBR 6118, Rio de Janeiro, 2003.

[08] Bazant, Z.P., Baweja, S. Creep and shrinkage prediction model for analysis and design of concrete structures (Model B3), In: AlManasseer, A., (Ed.), Creep and Shrinkage of Concrete, ACI Special Publication, (extended and improved version of Bazant and Baweja, 1995 a,b,c), 2000.

\section{Figure 15 - Experimental creep strains and predicted creep models}

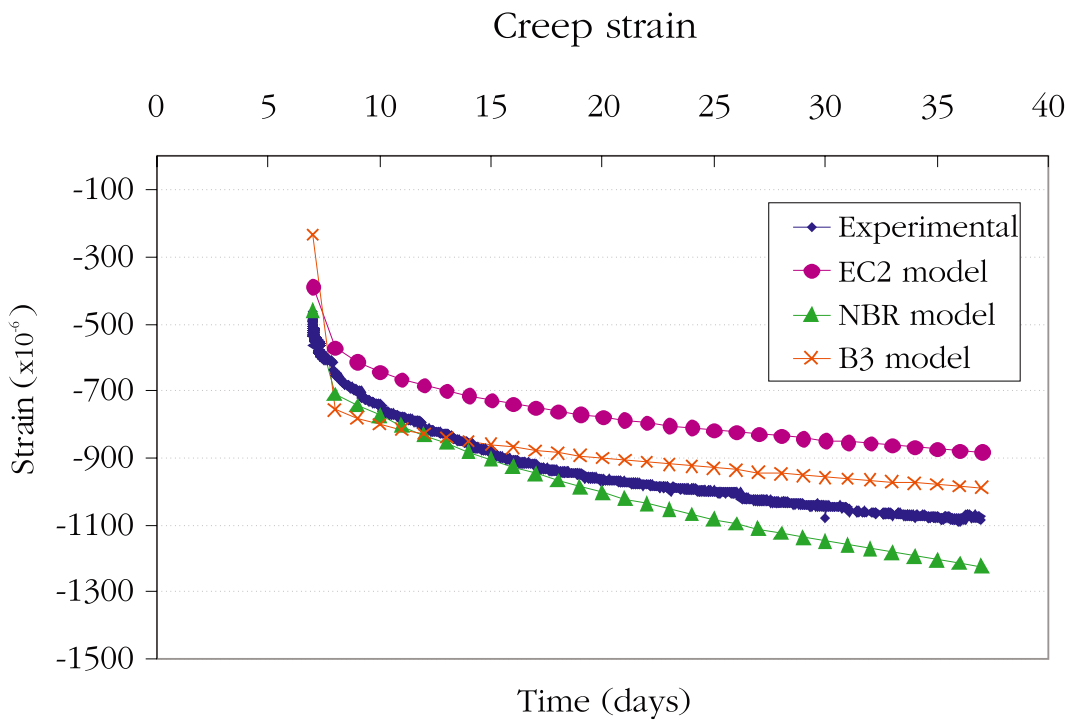

